Article

\title{
The Role of Support in Formic Acid Decomposition on Gold Catalysts
}

\author{
Vladimir Sobolev ${ }^{1, *}$, Igor Asanov 2,3 ${ }^{(D)}$ and Konstantin Koltunov 1,3 \\ 1 Boreskov Institute of Catalysis SB RAS, 630090 Novosibirsk, Russia; koltunov@catalysis.ru \\ 2 Nikolaev Institute of Inorganic Chemistry SB RAS, 630090 Novosibirsk, Russia; asan@niic.nsc.ru \\ 3 Department of Natural Sciences, Novosibirsk State University, 630090 Novosibirsk, Russia \\ * Correspondence: visobo@catalysis.ru; Tel.: +73-833-269-765
}

Received: 5 October 2019; Accepted: 1 November 2019; Published: 4 November 2019

\begin{abstract}
Formic acid (FA) can easily be decomposed, affording molecular hydrogen through a controllable catalytic process, thus attaining great importance as a convenient hydrogen carrier for hydrogen energetics. Supported gold nanoparticles are considered to be among the most promising catalysts for such applications. However, questions remain regarding the influence of the catalyst support on the reaction selectivity. In this study, we have examined the catalytic activity of typical gold catalysts, such as $\mathrm{Au} / \mathrm{TiO}_{2}, \mathrm{Au} / \mathrm{SiO}_{2}$, and $\mathrm{Au} / \mathrm{Al}_{2} \mathrm{O}_{3}$ in decomposition of FA, and then compared it with the catalytic activity of corresponding supports. The performance of each catalyst and support was evaluated using a gas-flow packed-bed reactor. It is shown that the target reaction, $\mathrm{FA} \rightarrow \mathrm{H}_{2}+$ $\mathrm{CO}_{2}$, is provided by the presence of gold nanoparticles, whereas the concurrent, undesirable pathway, such as $\mathrm{FA} \rightarrow \mathrm{H}_{2} \mathrm{O}+\mathrm{CO}$, results exclusively from the acid-base behavior of supports.
\end{abstract}

Keywords: hydrogen energetics; hydrogen carrier; formic acid dehydrogenation; supported gold catalysts

\section{Introduction}

Formic acid (FA) is one of the liquid organic hydrogen carriers (LOHC), which contains $4.4 \mathrm{wt} \%$ of hydrogen. This chemical is persistent and thus, can be safely stored, transported, and applied as a source of hydrogen for the needs of hydrogen energetics instead of difficult to handle molecular hydrogen [1-3]. Sufficient stability combined with low toxicity and low flammability provides additional advantages for the practical use of FA. It is important that FA can be produced sustainably from biomass $[4,5]$ or via reaction of $\mathrm{CO}_{2}$ with hydrogen, which can be obtained by electrolysis $[6,7]$. Another key point is that FA undergoes facile dehydrogenation over supported noble metal catalysts at mild conditions. In particular, it was reported that the activity of $\mathrm{Au} / \mathrm{Al}_{2} \mathrm{O}_{3}$ catalysts was higher compared to that of $\mathrm{Pt} / \mathrm{Al}_{2} \mathrm{O}_{3}$ catalysts in the gas-phase reaction [8]. Overall, the catalytic behavior of supported $\mathrm{Au}$ in the FA decomposition is influenced by the nature of the support $[9,10]$, the gold dispersion [8,11], and the use of basic cocatalysts [12-14].

In principle, FA can be decomposed through the desired path (1) to afford a mixture of molecular hydrogen and carbon dioxide or alternatively, FA can undergo dehydration to give concurrently highly undesirable carbon monoxide (path 2):

$$
\begin{aligned}
& \mathrm{HCOOH} \rightarrow \mathrm{CO}_{2}+\mathrm{H}_{2} \\
& \mathrm{HCOOH} \rightarrow \mathrm{CO}+\mathrm{H}_{2} \mathrm{O}
\end{aligned}
$$

It is noteworthy that despite significant efforts in finding efficient homo- and heterogeneous catalysts to address pathway (1), the achievement of near-theoretical-maximum selectivity of this 
reaction is still a challenging task. On the other hand, it was demonstrated recently that gold catalysts with the same gold content $(\sim 2.5 \mathrm{wt} \%)$ and mean Au-particles size (2.4-3.0 $\mathrm{nm})$ supported on $\mathrm{MgO}, \mathrm{La}_{2} \mathrm{O}_{3}, \mathrm{ZrO}_{2}, \mathrm{CeO}_{2}$, and $\mathrm{Al}_{2} \mathrm{O}_{3}$ have exhibited a clear volcano-type dependence of the $\mathrm{FA}$ decomposition along path (1) on the electronegativity of the support's cation, with the $\mathrm{Au} / \mathrm{Al}_{2} \mathrm{O}_{3}$ on the top [9]. Moreover, the latter catalyst has demonstrated the best selectivity and practically CO-free hydrogen production. Based on these findings, it was suggested that dehydrogenation of FA should be catalyzed by gold nanoparticles but only in combination with the acid-base activity of the support. It is significant in this context that the acid-base reactivity of metal oxides themselves toward dehydration/dehydrogenation of FA is also generally known [15-17]. However, the relative contribution of oxide support as part of the gold catalyst to pathways (1) and (2) remained uncertain.

In order to fill that gap, in this study, we have examined the catalytic behavior of gold catalysts, such as $\mathrm{Au} / \mathrm{Al}_{2} \mathrm{O}_{3}, \mathrm{Au} / \mathrm{TiO}_{2}$, and $\mathrm{Au} / \mathrm{SiO}_{2}$ in decomposition of $\mathrm{FA}$, and then compared it with the catalytic activity of corresponding supports. It is found that the undesirable pathway (2) results exclusively from the acid-base behavior of supports, regardless of the presence of gold.

\section{Materials and Methods}

Commercially available $\mathrm{Al}_{2} \mathrm{O}_{3}$ (A-201 La Roche Industries Inc.), $\mathrm{SiO}_{2}$ (Merck), and $\mathrm{TiO}_{2}$ (Aerolyst 7708 Degussa AG) have been used as oxide supports. The deposition of gold on the oxide supports was implemented by a direct ionic exchange method using ammonia according to a procedure elaborated by Ivanova et al. [18]. An aqueous $5 \times 10^{-4} \mathrm{M}$ solution of $\mathrm{HAuCl}_{4}(99.9 \%, \mathrm{ABCR}$, Darmstadt, Germany) was mixed with a support in a ratio corresponding to the Au concentration of $2 \mathrm{wt} \%$. After stirring at $70{ }^{\circ} \mathrm{C}$ for $2 \mathrm{~h}$, a $4 \mathrm{M}$ solution of ammonia was added. The suspension thus obtained was stirred at $70{ }^{\circ} \mathrm{C}$ for an additional $1 \mathrm{~h}$, then filtered off and washed with water. The samples were dried overnight at $80{ }^{\circ} \mathrm{C}$ and calcined at $300{ }^{\circ} \mathrm{C}$ for $4 \mathrm{~h}$.

The specific surface area of the catalysts was determined from $\mathrm{N}_{2}$ adsorption isotherms at $77.3 \mathrm{~K}$ on a Quadrosorb evo (Quantachrome Instruments, USA) analyzer after degassing the samples with the use of a FLOVAC Degasser (Quantachrome Instruments, USA) instrument.

XPS study was performed with a SPECS Phoibos 150 (Germany) photoelectron spectrometer. The spectra were recorded using an AlK $\alpha$ source with quantum energy of $1486.6 \mathrm{eV}$. The energy scale was calibrated against the binding energy of gold $\mathrm{Au} 4 \mathrm{f}_{7 / 2}$ equal to $84.0 \mathrm{eV}$. A carbon $\mathrm{C} 1 \mathrm{~s}$ peak for hydrocarbon impurities at $285.0 \mathrm{eV}$ was used as a reference for the energy scale calibration.

The gold content in the catalysts was determined by inductively coupled plasma optical emission spectrometry (ICP-OES) using an Optima 5300 DV (Perkin-Elmer) instrument. The samples (50 mg) were dissolved in $5 \mathrm{ml}$ of imperial water $\left(2 \mathrm{HNO}_{3}\right.$ and $\left.6 \mathrm{HCl}\right)$. The solutions obtained were diluted with water to $100 \mathrm{ml}$ and then analyzed.

Transmission electron microscopy (TEM) was performed with a Zeiss LEO 912 OMEGA (Germany) microscope at an acceleration voltage of $120 \mathrm{kV}$. To determine the mean diameter of Au particles, more than 100 particles were chosen.

The gas-phase decomposition of formic acid was performed in a quartz tube flow reactor with an internal diameter of $6 \mathrm{~mm}$. Activity tests were carried out at atmospheric pressure using $20 \mathrm{mg}$ of a catalyst mixed with $0.5 \mathrm{~mL}$ of quartz sand $(\mathrm{d}=0.25 \mathrm{~mm})$. The overall length of the catalyst layer was $\sim 20 \mathrm{~mm}$. The gas mixture ( $5 \mathrm{vol} \%$ formic acid in $\mathrm{He}$ ) was fed at a rate of $20 \mathrm{~mL} \mathrm{~min}{ }^{-1}$. The experiments were carried out in the temperature-programmed mode. The heating rate was $2{ }^{\circ} \mathrm{C} \mathrm{min}^{-1}$. The reaction temperature was measured with a thermocouple inserted into the catalyst bed. In order to achieve reproducible results, prior to activity measurements, the catalysts were pretreated in the reactor according to a standard procedure: heating at $300{ }^{\circ} \mathrm{C}$ in a flow of $5 \mathrm{vol} \% \mathrm{HCOOH}$ in $\mathrm{He}$ for $15 \mathrm{~min}$, which ensured the in situ reduction conditions. Then the catalysts were cooled in the same mixture to the reaction temperature. The progress of the reaction was monitored by gas chromatography, judged by the production of $\mathrm{CO}$ and $\mathrm{CO}_{2}$, as described earlier [19]. 


\section{Results}

\subsection{Catalysts Characterization}

It is known that the most active gold catalysts contain small gold particles, which are less than $10 \mathrm{~nm}$ in diameter, especially on such supports as reducible $\mathrm{TiO}_{2}$. With this in mind, samples of $\mathrm{Au} / \mathrm{TiO}_{2}, \mathrm{Au} / \mathrm{Al}_{2} \mathrm{O}_{3}$, and $\mathrm{Au} / \mathrm{SiO}_{2}$ with a gold content of $\sim 2 \mathrm{wt} \%$ and an average gold particle size below $3 \mathrm{~nm}$ were prepared. The gold particle size was estimated by TEM. The particle size distribution of $\mathrm{Au} / \mathrm{TiO}_{2}, \mathrm{Au} / \mathrm{Al}_{2} \mathrm{O}_{3}$, and $\mathrm{Au} / \mathrm{SiO}_{2}$ samples are shown in Figure 1. The gold loading in the prepared samples was determined by using ICP-OES. The exact loadings of $\mathrm{Au}$, the surface areas of the catalysts found by BET, and the average sizes of gold particles are stated in Table 1.

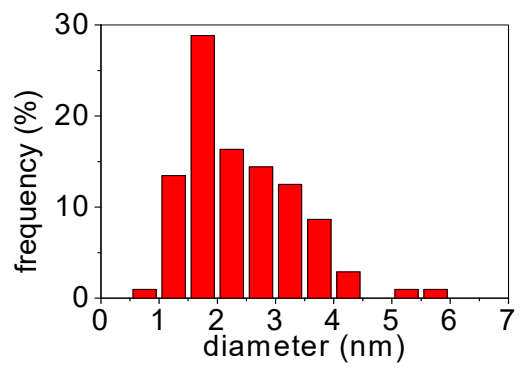

(a)

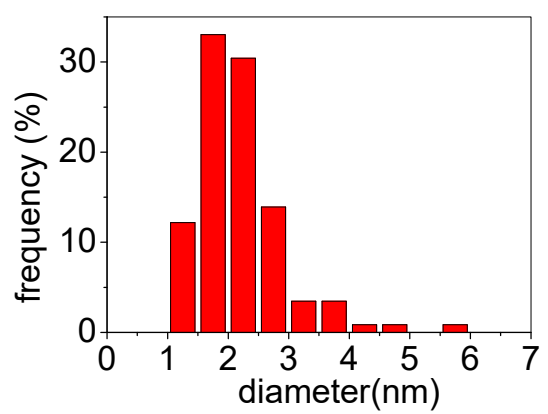

(b)

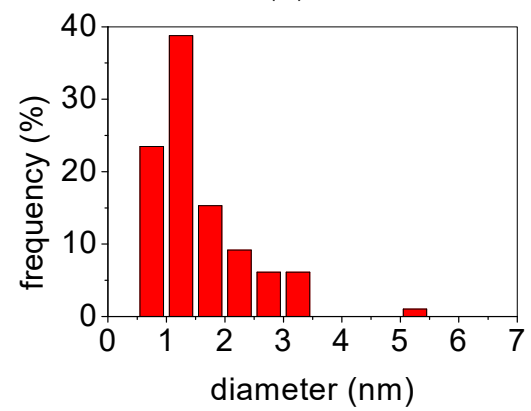

(c)

Figure 1. Particle size distribution of (a) $\mathrm{Au} / \mathrm{TiO}_{2}$, (b) $\mathrm{Au} / \mathrm{Al}_{2} \mathrm{O}_{3}$, (c) $\mathrm{Au} / \mathrm{SiO}_{2}$ catalysts.

Table 1. Characteristics of Au-based catalysts and corresponding supports.

\begin{tabular}{cccc}
\hline Sample & Au Loading $\mathbf{( w t} \%)$ & $\boldsymbol{S}_{\text {BET }}\left(\mathbf{m}^{\mathbf{2}} \cdot \mathbf{g}^{\mathbf{- 1}}\right)$ & Average Size of Au Particles $(\mathbf{n m})$ \\
\hline $\mathrm{TiO}_{2}$ & - & 45 & - \\
$\mathrm{Au} / \mathrm{TiO}_{2}$ & 1.9 & 45 & $2.4 \pm 0.9$ \\
$\mathrm{Al}_{2} \mathrm{O}_{3}$ & - & 200 & - \\
$\mathrm{Au} / \mathrm{Al}_{2} \mathrm{O}_{3}$ & 1.8 & 199 & $2.2 \pm 1.0$ \\
$\mathrm{SiO}_{2}$ & - & 480 & - \\
$\mathrm{Au} / \mathrm{SiO}_{2}$ & 2.1 & 440 & $1.6 \pm 0.8$ \\
\hline
\end{tabular}


The Au catalysts were also characterized by XPS in order to gain insight into the electronic state of $\mathrm{Au}$. The XPS showed the presence of $\mathrm{Au}$ in the metallic state only ( $\mathrm{Au} 4 \mathrm{f}_{7 / 2} \sim 84.0 \mathrm{eV}$ ) (Figure 2), while the nature of the support did not influence notably the electronic state of Au. However, the deconvolution of the XPS spectra revealed the existence of metallic gold with peaks shifted towards lower binding energies. This can be related to divers phenomena-the electron transfer from the support to particles of gold $[20,21]$ and/or to a dominant effect of the atoms at low coordinated sites present in small particles, as it was proposed by Radnik et al. [22,23].

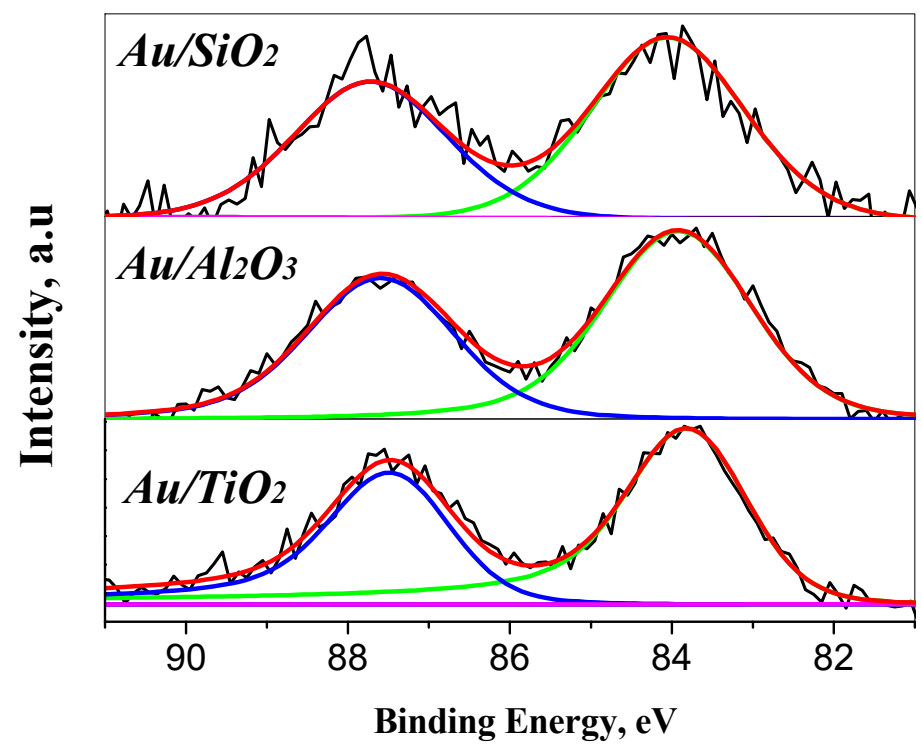

Figure 2. XPS of gold-containing catalysts in the Au $4 \mathrm{f}$ region.

\subsection{Catalytic Activity}

The catalytic performance of the oxide supported gold catalysts is shown in Figure 3. Despite the comparable content of gold $(\sim 2 \mathrm{wt} \%)$ and mean Au-particles size $(\sim 2 \mathrm{~nm})$, the catalytic properties of $\mathrm{Au} / \mathrm{TiO}{ }_{2}, \mathrm{Au} / \mathrm{SiO}_{2}$, and $\mathrm{Au} / \mathrm{Al}_{2} \mathrm{O}_{3}$ samples in the FA decomposition are notably different. The relative activity of the catalysts turned out to be as follows: $\mathrm{Au} / \mathrm{TiO}_{2}>\mathrm{Au} / \mathrm{SiO}_{2}>\mathrm{Au} / \mathrm{Al}_{2} \mathrm{O}_{3}$. Complete conversion of FA was achieved at $190{ }^{\circ} \mathrm{C}$ for $\mathrm{Au} / \mathrm{TiO}{ }_{2}$, whereas for $\mathrm{Au} / \mathrm{Al}_{2} \mathrm{O}_{3}$ and $\mathrm{Au} / \mathrm{SiO}_{2}$, the $\mathrm{FA}$ conversion had attained only 5 and $15 \%$ at the same conditions. However, decomposition of FA occurred by different pathways. The most active catalyst, $\mathrm{Au} / \mathrm{TiO}_{2}$, provided mainly undesirable pathway (2) to give $\mathrm{CO}$ and $\mathrm{H}_{2} \mathrm{O}$. For this catalyst, the selectivity towards $\mathrm{H}_{2}$ formation was below $5 \%$ at complete conversion of FA. In contrast, decomposition of FA on $\mathrm{Au} / \mathrm{Al}_{2} \mathrm{O}_{3}$ and $\mathrm{Au} / \mathrm{SiO}_{2}$ afforded mostly $\mathrm{H}_{2}$ and $\mathrm{CO}_{2}$ with a selectivity of $\sim 80 \%$ (at complete conversion of FA).

For illustration, the long-term performance of $\mathrm{Au} / \mathrm{SiO}_{2}$ in the $\mathrm{FA}$ decomposition is presented in Figure 4 . As can be seen, the catalytic activity and reaction selectivity practically did not change, even after FA dehydrogenation for $5 \mathrm{~h}$ at $228^{\circ} \mathrm{C}$.

Figure 5 shows the catalytic activity of $\mathrm{Au} / \mathrm{SiO}_{2}, \mathrm{Au} / \mathrm{Al}_{2} \mathrm{O}_{3}$, and $\mathrm{Au} / \mathrm{TiO}_{2}$ samples versus that of the corresponding oxide supports. It is definitely seen that the catalytic performance of $\mathrm{Au} / \mathrm{TiO}_{2}$ relies almost entirely on the action of $\mathrm{TiO}_{2}$ (Figure 5c). Unfortunately, $\mathrm{TiO}_{2}$ (and therefore, $\mathrm{Au} / \mathrm{TiO}_{2}$ ) is more inclined to catalyze dehydration of FA on its acid sites [17], thus demonstrating comparatively poor catalytic activity towards the desirable path (1). 

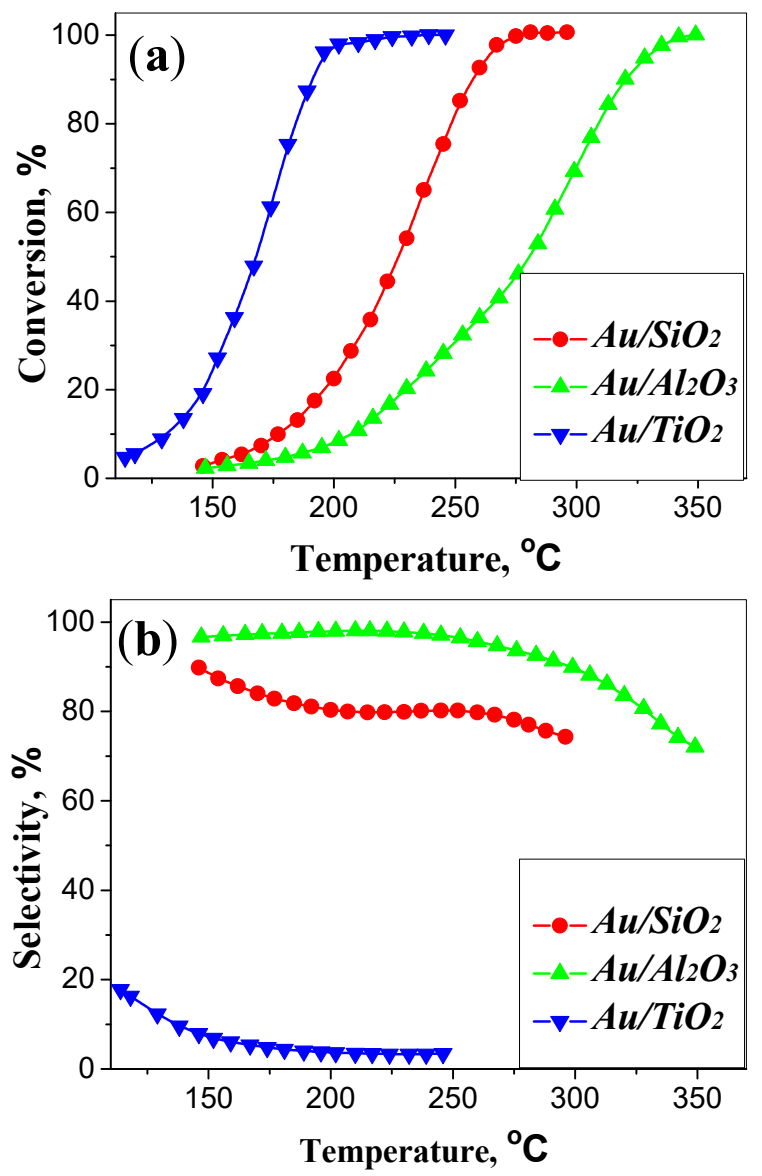

Figure 3. Conversion of formic acid (FA) (a) and selectivity to $\mathrm{H}_{2}$ and $\mathrm{CO}_{2}$ formation (b) in the decomposition of FA as a function of temperature on gold-containing catalysts.

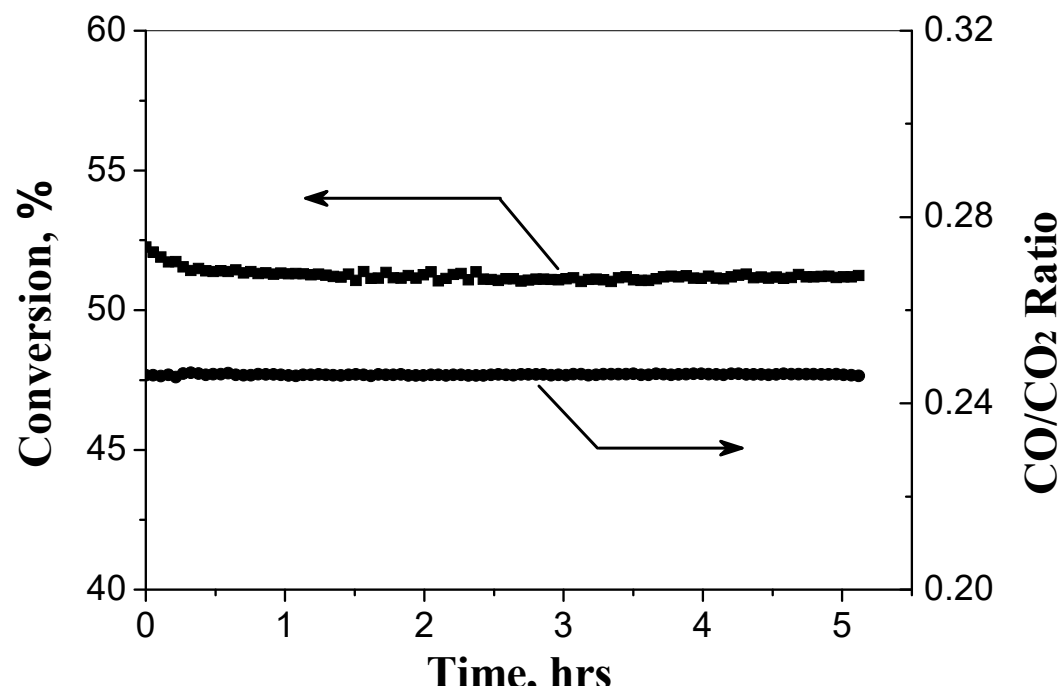

Figure 4. Long-term $\mathrm{FA}$ decomposition on $\mathrm{Au} / \mathrm{SiO}_{2}$ at $228^{\circ} \mathrm{C}$. 

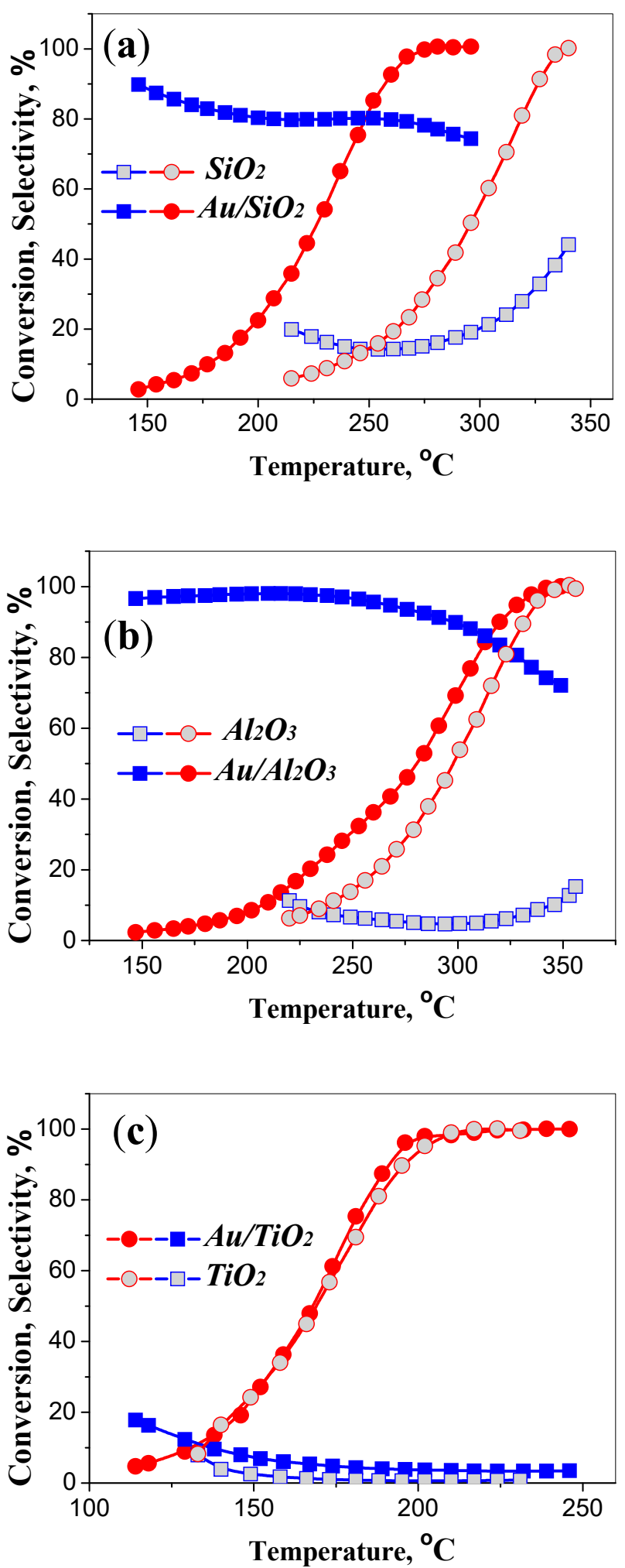

Figure 5. Conversions of $\mathrm{FA}$ (cycles) and selectivities to $\mathrm{H}_{2}$ and $\mathrm{CO}_{2}$ formation (squares) in the decomposition of FA on (a) $\mathrm{Au} / \mathrm{SiO}_{2}$ and $\mathrm{SiO}_{2}$; (b) $\mathrm{Au} / \mathrm{Al}_{2} \mathrm{O}_{3}$ and $\mathrm{Al}_{2} \mathrm{O}_{3} ;$ (c) $\mathrm{Au} / \mathrm{TiO}_{2}$ and $\mathrm{TiO}_{2}$.

In contrast, $\mathrm{SiO}_{2}$ itself has shown much lower catalytic activity compared to $\mathrm{Au} / \mathrm{SiO}_{2}$ (Figure 5a). The selectivity to $\mathrm{FA}$ dehydrogenation on $\mathrm{SiO}_{2}$ is comparatively low and inversely associated with $\mathrm{FA}$ dehydration. Pure $\mathrm{Al}_{2} \mathrm{O}_{3}$ behaves in a similar way. The selectivity of FA conversion to $\mathrm{H}_{2}$ and $\mathrm{CO}_{2}$ is very low (Figure $5 b$ ). Thus, none of the oxide supports has demonstrated significant selectivity for $\mathrm{H}_{2}$ 
production. On the contrary, their acid-base properties lead mainly to the undesirable decomposition of FA by pathway (2).

In general, these observations are in accordance with recent findings on the enhanced selectivity to hydrogen formation in FA decomposition over gold and other metals supported on an inert support, such as carbon or carbon doped with nitrogen [14,24-27]. However, these results were considered mainly in terms of the increased catalytic activity of corresponding catalysts toward FA dehydrogenation. In our vision, the oxide supports, such as $\mathrm{SiO}_{2}, \mathrm{Al}_{2} \mathrm{O}_{3}$, and especially $\mathrm{TiO}_{2}$, strongly compete with the target reaction, promoting acid-catalyzed dehydration of FA.

\section{Conclusions}

It is shown that the oxide support (regardless of whether it is $\mathrm{TiO}_{2}, \mathrm{Al}_{2} \mathrm{O}_{3}$, or $\mathrm{SiO}_{2}$ ) does not affect the electronic state of the supported nanoparticles of gold, which exist in the metallic state. However, a notable effect of the oxide support on the selectivity of hydrogen production from FA decomposition is found. The target reaction (FA $\rightarrow \mathrm{H}_{2}+\mathrm{CO}_{2}$ ) competes strongly with dehydration of FA due to the acid-base properties of the supports in the order given: $\mathrm{TiO}_{2}>\mathrm{Al}_{2} \mathrm{O}_{3} \sim \mathrm{SiO}_{2}$. Hence, the results of this study can be applied for the development of supported gold catalysts with the diminished acidity of supports for the selective hydrogen production via FA decomposition.

Author Contributions: Catalytic measurements, data analysis, and text editing, V.S.; data analysis and writing, K.K.; XPS measurements, I.A.

Funding: This work was conducted within the framework of the budget project for the Boreskov Institute of Catalysis (No. AAAA-A17-117041710083-5).

Conflicts of Interest: The authors declare no conflict of interest.

\section{References}

1. Gianotti, E.; Taillades-Jacquin, M.; Roziere, J.; Jones, D.J. High-Purity Hydrogen Generation Via Dehydrogenation of Organic Carriers: A Review on the Catalytic Process. ACS Catal. 2018, 8, 4660-4680. [CrossRef]

2. Niermann, M.; Beckendorff, A.; Kaltschmitt, M.; Bonhoff, K. Liquid Organic Hydrogen Carrier (LOHC)-Assessment Based on Chemical and Economic Properties. Int. J. Hydrogen Energy 2019, 44, 6631-6654. [CrossRef]

3. Zhong, H.; Iguchi, M.; Chatterjee, M.; Himeda, Y.; Xu, Q.; Kawanami, H. Formic Acid-Based Liquid Organic Hydrogen Carrier System with Heterogeneous Catalysts. Adv. Sustain. Syst. 2018, 2, 1700161. [CrossRef]

4. Bulushev, D.A.; Ross, J.R.H. Towards Sustainable Production of Formic Acid. ChemSusChem 2018, 11, 821-836. [CrossRef] [PubMed]

5. Preuster, P.; Albert, J. Biogenic Formic Acid as a Green Hydrogen Carrier. Energy Technol. 2018, 6, 501-509. [CrossRef]

6. Bulushev, D.A.; Ross, J.R.H. Heterogeneous Catalysts for Hydrogenation of $\mathrm{CO}_{2}$ and Bicarbonates to Formic Acid and Formates. Catal. Rev. 2018, 60, 566-593. [CrossRef]

7. Wang, W.H.; Himeda, Y.; Muckerman, J.T.; Manbeck, G.F.; Fujita, E. $\mathrm{CO}_{2}$ Hydrogenation to Formate and Methanol as an Alternative to Photo- and Electrochemical $\mathrm{CO}_{2}$ Reduction. Chem. Rev. 2015, 115, 12936-12973. [CrossRef]

8. Ojeda, M.; Iglesia, E. Formic Acid Dehydrogenation on Au-Based Catalysts at near-Ambient Temperatures. Angew. Chem. Int. Ed. 2009, 48, 4800-4803. [CrossRef]

9. Zacharska, M.; Chuvilin, A.L.; Kriventsov, V.V.; Beloshapkin, S.; Estrada, M.; Simakov, A.; Bulushev, D.A. Support Effect for Nanosized Au Catalysts in Hydrogen Production from Formic Acid Decomposition. Catal. Sci. Technol. 2016, 6, 6853-6860. [CrossRef]

10. Gazsi, A.; Bansagi, T.; Solymosi, F. Decomposition and Reforming of Formic Acid on Supported Au Catalysts: Production of CO-Free H2. J. Phys. Chem. C 2011, 115, 15459-15466. [CrossRef] 
11. Singh, S.; Li, S.; Carrasquillo-Flores, R.; Alba-Rubio, A.C.; Dumesic, J.A.; Mavrikakis, M. Formic Acid Decomposition on Au Catalysts: DFT, Microkinetic Modeling, and Reaction Kinetics Experiments. AIChE J. 2014, 60, 1303-1319. [CrossRef]

12. Bulushev, D.A.; Zacharska, M.; Guo, Y.; Beloshapkin, S.; Simakov, A. CO-Free Hydrogen Production from Decomposition of Formic Acid over $\mathrm{Au} / \mathrm{Al}_{2} \mathrm{O}_{3}$ Catalysts Doped with Potassium Ions. Catal. Commun. 2017, 92, 86-89. [CrossRef]

13. Jia, L.; Bulushev, D.A.; Beloshapkin, S.; Ross, J.R.H. Hydrogen Production from Formic Acid Vapour over a $\mathrm{Pd} / \mathrm{C}$ Catalyst Promoted by Potassium Salts: Evidence for Participation of Buffer-Like Solution in the Pores of the Catalyst. Appl. Catal. B Environ. 2014, 160, 35-43. [CrossRef]

14. Bulushev, D.A.; Sobolev, V.I.; Pirutko, L.V.; Starostina, A.V.; Asanov, I.P.; Modin, E.; Chuvilin, A.L.; Gupta, N.; Okotrub, A.V.; Bulusheva, L.G. Hydrogen Production from Formic Acid over Au Catalysts Supported on Carbon: Comparison with Au Catalysts Supported on $\mathrm{SiO}_{2}$ and $\mathrm{Al}_{2} \mathrm{O}_{3}$. Catalysts 2019, 9, 376. [CrossRef]

15. Trillo, J.M.; Munera, G.; Criado, J.M. Catalytic decomposition of formic acid on metal oxides. Catal. Rev. 1972, 7, 51-86. [CrossRef]

16. Patermarakis, $\mathrm{G}$. The parallel dehydrative and dehydrogenative catalytic action of $\gamma-\mathrm{Al}_{2} \mathrm{O}_{3}$ pure and doped by MgO. Appl. Catal. A 2003, 252, 231-241. [CrossRef]

17. Sobolev, V.I.; Koltunov, K.Y. Oxidative and non-oxidative degradation of $\mathrm{C}_{1}-\mathrm{C}_{3}$ carboxylic acids over $\mathrm{V}_{2} \mathrm{O}_{5} / \mathrm{TiO}_{2}$ and $\mathrm{MoVTeNb}$ oxides: A comparative study. Appl. Catal. A Gen. 2013, 466, 45-50. [CrossRef]

18. Ivanova, S.; Pitchon, V.; Zimmermann, Y.; Petit, C. Preparation of Alumina Supported Gold Catalysts: Influence of Washing Procedures, Mechanism of Particles Size Growth. Appl. Catal. A Gen. 2006, 298, 57-64. [CrossRef]

19. Bulushev, D.A.; Chuvilin, A.L.; Sobolev, V.I.; Stolyarova, S.G.; Shubin, Y.V.; Asanov, I.P.; Ishchenko, A.V.; Magnani, G.; Ricco, M.; Okotrub, A.V.; et al. Copper on Carbon Materials: Stabilization by Nitrogen Doping. J. Mater. Chem. A 2017, 5, 10574-10583. [CrossRef]

20. Claus, P.; Bruckner, A.; Mohr, C.; Hofmeister, H. Supported Gold Nanoparticles from Quantum Dot to Mesoscopic Size Scale: Effect of Electronic and Structural Properties on Catalytic Hydrogenation of Conjugated Functional Groups. J. Am. Chem. Soc. 2000, 122, 11430-11439. [CrossRef]

21. Sanchez, A.; Abbet, S.; Heiz, U.; Schneider, W.-D.; Hakkinen, H.; Barnett, R.N.; Landman, U. When Gold Is Not Noble: Nanoscale Gold Catalysts. J. Phys. Chem. A 1999, 103, 9573-9578. [CrossRef]

22. Radnik, J.; Mohr, C.; Claus, P. On the Origin of Binding Energy Shifts of Core Levels of Supported Gold Nanoparticles and Dependence of Pretreatment and Material Synthesis. Phys. Chem. Chem. Phys. 2003, 5 , 172-177. [CrossRef]

23. Pohl, M.-M.; Radnik, J.; Schneider, M.; Bentrup, U.; Linke, D.; Bruckner, A.; Ferguson, E. Bimetallic $\mathrm{PdAu}-\mathrm{KOac} / \mathrm{SiO}_{2}$ catalysts for vinyl acetate monomer (VAM) synthesis: Insights into deactivation under industrial conditions. J. Catal. 2009, 262, 314-323. [CrossRef]

24. Tang, C.; Surkus, A.-E.; Chen, F.; Pohl, M.-M.; Agostini, G.; Schneider, M.; Junge, H.; Beller, M. A Stable Nanocobalt Catalyst with Highly Dispersed $\mathrm{CoN}_{\mathrm{x}}$ Active Sites for the Selective Dehydrogenation of Formic Acid. Angew. Chem. Int. Ed. 2017, 56, 16616-16620. [CrossRef]

25. Sanchez, F.; Alotaibi, M.H.; Motta, D.; Chan-Thaw, C.E.; Rakotomahevitra, A.; Tabanelli, T.; Roldan, A.; Hammond, C.; He, Q.; Davies, T.; et al. production from formic acid decomposition in the liquid phase using Pd nanoparticles supported on CNFs with different surface properties. Sustain. Energy Fuels 2018, 2, 2705-2716. [CrossRef]

26. Sanchez, F.; Motta, D.; Roldan, A.; Hammond, C.; Villa, A.; Dimitratos, N. Hydrogen Generation from Additive-Free Formic Acid Decomposition Under Mild Conditions by Pd/C: Experimental and DFT Studies. Top. Catal. 2018, 61, 254-266. [CrossRef]

27. Sanchez, F.; Motta, D.; Bocelli, L.; Albonetti, S.; Roldan, A.; Hammond, C.; Villa, A.; Dimitratos, N. Investigation of the Catalytic Performance of $\mathrm{Pd} / \mathrm{CNFs}$ for Hydrogen Evolution from Additive-Free Formic Acid Decomposition. C J. Carbon Res. 2018, 4, 26. [CrossRef]

(C) 2019 by the authors. Licensee MDPI, Basel, Switzerland. This article is an open access article distributed under the terms and conditions of the Creative Commons Attribution (CC BY) license (http://creativecommons.org/licenses/by/4.0/). 